Dutch nuclear issues

\section{Decisions later}

Waalre, The Netherlands

THE Dutch preoccupation with nuclear energy, military and peaceful, will continue for at least another eighteen months. That is the effect of the decision of the Dutch Parliament on 13 June that a final decision on the siting of US cruise missiles in the Netherlands will be made only at the end of 1985. The Netherlands is the only country out of step with the policy of the North Atlantic Treaty Organization (NATO) in this respect.

Never has a subject been discussed so feverishly in the Netherlands. Only the political parties on the right (conservatives and four smaller parties) are in favour of deployment of the missiles, but, according to opinion polls, voters are against the siting plan. On the left, the socialists and three small parties are against, as are the great majority of their voters. The role of the Christian democrats, which together with the conservatives form the government, is especially confusing. Their voters are sharply divided, and they are under heavy pressure from the churches which in advance of 13 June issued declarations asking the government not to install the missiles and in the process offended some church people who hold that the declarations were "too political".

Similarly, the development of civil nuclear power in the Netherlands is on ice, with more than half of the population against it. There are two small nuclear plants (of 60 and $470 \mathrm{MW}$ ) now operating, and ten years ago the government proposed building three $1,000-\mathrm{MW}$ plants. But that plan was shelved after a year and a half because of the strength of the opposition, unabated by the oil crisis. But discussion continues, with the churches and the environmental movement playing a prominent part.

Earlier this year (see Nature 307, 405; 1984), it seemed the issue had been settled by the report of the officially organized public consultation which in the previous two years had gathered evidence for its conclusion that further nuclear plants are now necessary and that combined heat and power schemes, in industry and domestic applications as well as wind power, should replace obsolete plants in the 1990 s. But now it seems that the government is brooding on plans to expand nuclear capacity by $4,000 \mathrm{MW}$, and leading newspapers have been complaining that this overrides the democratic consultation the government itself had organized.

The government's plans for nuclear power will in fact be published in September but meanwhile the minister of economic affairs, Gijs Van Aardenne, who was unenthusiastic about the report on nuclear power published in January, does not conceal his enthusiasm for further development, while Prime Minister Ruud
Lubbers, in 1974 the minister of economic affairs who put forward the earlier nuclear power plan, is also a supporter.

So the months ahead will be another test for democracy in the Netherlands. Although the debate about the missiles will continue for 18 months, it is barely conceivable that the Netherlands will not follow its NATO partners, despite five years of public demonstrations and social unrest. And the development of nuclear power may follow the same route.

Casper Schuuring

\section{UK science budget Money needed}

THE British Government's advisers on the share-out of the civil science budget have warned Members of Parliament of the dire consequences for the nation's research enterprise unless greater provision is made for science over the next decade.

The House of Commons Select Committee on Education, Science and the Arts, which has started an inquiry into the science budget, heard last week from the Advisory Board for the Research Councils (ABRC), represented by its chairman, Sir David Philips, Dr Walter Bodmer, director of research of the Imperial Cancer Research Fund, and Dr Derek Roberts of General Electric Company Ltd. On the basis of published government expenditure estimates, ABRC predicts that the real value of scientific research is set to decrease by 25 per cent over the next decade.

This stark prediction arises from a number of effects that diminish the value of the research budget, which at first sight is planned to remain roughly constant in real terms. Firstly, according to ABRC, the science vote has had largely to compensate for an 11 per cent cut in recent years to university support of science from the University Grants Committee. Secondly, the Treasury's assumed annual cash increase for the science vote, which decreases from 3 per cent per year to 2.5 per cent per year over the next decade, is fully 2 per cent less than the Treasury's estimated annual increase in the retail price index. This alone would produce a decrease of 17 per cent over the 10 years in real terms.

On top of this, there is the problem of superannuation payments for the increasing number of retired research council staff. And the perennial problem of subscriptions to international organizations still remains. ABRC members emphasized last week their conviction that science had lost out in recent years in relation to other publicly supported activities, while the increasing sophistication of scientific equipment has meant that the same amount of money bought less. And they were disturbed that the government's published expenditure plans include no special reference to the value of science in the economy.

Tim Beardsley
Acid rain

\section{UK in minority of one}

THE British reputation for waywardness in the eyes of many Europeans seems unlikely to be improved this week at the World Conference on the Environment, taking place in Munich at the behest of the government of West Germany to discuss ways of combating atmospheric pollution. At the opening session on Monday, Dr Martin Holdgate, chief scientist of the British Department of the Environment, declined to give any firm commitment to reduce British emissions of sulphur dioxide, saying only that a range of measures was being considered that would allow Britain to reduce emissions "in a cost-effective way".

In Germany, acute concern over damage to forests is leading to pressure for drastic reductions in acidic emissions, chiefly sulphur dioxide from power stations and nitrogen oxides. But Dr Derek Pooley, chief scientist at Britain's Department of Energy, said last week he was "convinced that sulphur dioxide was not the major culprit in causing damage to forests".

A major study on acid deposition published last week by the department's energy technology support unit emphasizes the uncertainties. Forest damage appears not to correlate well with sulphur dioxide concentration when dry deposition from local sources is excluded. But above an altitude of 600 metres, which is where most of the damage occurs, photochemically produced ozone can reach sustained and high concentrations. Although no mechanism for ozone damage is known, one suggestion made in the Department of Energy's study is that ozone causes damage to leaf cuticle, which in turn allows leaching of magnesium as the $p \mathrm{H}$ falls. But Dr Bill Binns of the Forestry Commission, who has made

\section{Cost of impure mice}

\section{Washington}

A UNIVERSITY of Wisconsin researcher has won an out-of-court settlement with Charles River Breeding Laboratories over a mix-up of mice that the researcher said caused her to waste a year's work and set back her career. Dr Brenda Kahan will receive an undisclosed monetary settlement; in addition, the University of Wisconsin will receive $\$ 40,000$ from Charles River as compensation for research and overhead expenses of the invalidated research. Two-thirds of that $\$ \mathbf{4 0 , 0 0 0}$ will support Kahan's research.

Charles River, a major supplier of laboratory mice, shipped large numbers of genetically impure mice to researchers who believed they were getting a pure strain. The company says it has now corrected the problem.

Stephen Budiansky 
several studies of forest damage in West Germany, is not so quick to rule out a role for sulphur dioxide. He emphasizes that "occult" precipitation - fog and mist can be much more acidic than rain and may yet play a part, perhaps in conjunction with other stress factors.

If there is still mystery over the mechanism of damage to trees, the mechanism of damage to fish in fresh water is rather better understood. It seems that elevated levels of inorganic aluminium may be a major cause of mortality. But the chemical changes that will occur in a body of water subjected to acid deposition within its catchment area are greatly affected by the nature of the soil and bedrock, as well as by the type of vegetation present. It is clear that coniferous trees, in particular, can efficiently filter out acids from the air and release these in solution at the next rainfall. The Forestry Commission in Britain is already investigating management practices that may reduce acid release into streams.

Because of the multitude of factors that affect acid depositions, the precise attribution of blame is difficult or impossible. Motor vehicles, for example, along with power stations may be (indirectly) a major source of ozone, through their emissions of nitrogen oxides. But the British contingent at Munich this week will doubtless be able to make much of new estimates published by the Department of Energy of the proportion of British-emitted sulphur dioxide that finds its way to other countries: 3.6 per cent to West Germany, 4.4 per cent to Norway and Sweden combined, while almost 30 per cent stays in Britain.

While the British Department of Energy harks on the quantitative uncertainties of acid deposition, the Nature Conservancy Council, which also last week published its views on the matter, takes a somewhat different line. It argues that acidification reduces species diversity in aquatic systems and that the only long-term solution to the problem is therefore to reduce emissions of sulphur and nitrogen oxides. And it is opposed to the policy of liming affected waters on the grounds that the practice will in the long term bring its own undesirable effects.

The British Government seems likely to find itself increasingly isolated over acid emissions. The government is commited to reply before the end of the current parliamentary session to the latest report of the Royal Commission on Environmental Pollution, which urged that the Central Electricity Generating Board should introduce emission abatement measures on a pilot basis. And the Select Committee on the Environment of the House of Commons is shortly to report on the results of its inquiry into "acid rain", which, it may be guessed, will not take a complacent view. It seems likely that political pressure will before long force some government concessions.

Tim Beardsley

Pesticides

\section{New chemicals under fire}

THE latest returns in a two-year survey of the British barn owl population suggest an even greater population decline than had been feared. Ten years ago there were some 4,500-9,000 pairs in England, Scotland and Wales and now, after 18 months of the "Barn Owl Survey" organized by the Hawk Trust, the indications are that the overall decline has been at least 10 per cent, with much greater reductions in many areas.

The only areas where there has been little decline are in Scotland, where the Forestry Commission's activities have provided some additional refuge for the dwindling population. The population estimates, however, are becoming increasingly inexact as the numbers involved get smaller.

The continued decline of the barn owl is thought, says Colin Shawyer of the Hawk Trust, to be a result of the use of new rodenticides by British farmers. Difenacoum and brodifacoum have been growing in popularity in the past few years, steadily replacing warfarin, which is known to be relatively non-toxic to species other than rodents. Brodifacoum is thought to be especially toxic to birds and for that reason has not been given full approval by the Ministry of Agriculture, Fisheries and Food under the Pesticides Safety Precautions Scheme.

Some of the evidence for the effects of the new pesticides comes from Malaysia. On some oil palm plantations, the combination of warfarin and the wild barn owls, encouraged by the provision of nestboxes on poles throughout the plantations, has effectively controlled severe rat infestations. But even on estates where there has been no evidence of warfarin resistance, the new pesticides have been tried. And, says the Hawk Trust, barn owl numbers declined so rapidly that the estate managers went back to the old methods.

In Britain, some farmers have reported

Victims both - a barn owl and prey. to the Hawk Trust that barn owls seemed to disappear from their farms soon after they started using the "second generation" rodent baits. And a veterinary surgeon reported that a barn owl thought to be dying from the effects of difenacoum poisoning was successfully treated by the vitamin $\mathrm{K}$ antidote to the pesticide.

Much of the evidence on pesticide toxicity is circumstantial, the Hawk Trust concedes. So the urgent need is for more research on the effects of the new chemicals on non-target species.

Charles Wenz

\section{Irreproducing ibis Tokyo}

EFFORTS to save Japan's Nipponia Nippon (the Japanese crested ibis or "toki") seem doomed to failure after a romance between two of the remaining birds - Kin (the female) and Midori (the male) — ended in a mid-mating season fight. As Kin is now, in human terms, around 80 years old, the chances of a successful mating next year are thought to be close to nil, although hormones are to be administered in the hope of keeping her in breeding condition.

The toki, a large white bird with a characteristic long downwardly curved black bill and a red face, was a common sight in wet paddy fields and ponds throughout Japan and parts of east Asia as recently as one hundred years ago. But a catastrophic decline in their numbers this century led to their being given special status in Japan in 1934. The war prevented any serious conservation measures, however, and by 1953 only 31 birds remained.

In 1966, special measures were begun but numbers continued to decline so, in 1981, the remaining five wild birds and one captive bird were removed to a breeding centre on the island of Sado - where in bygone days troublesome cadet branches of the imperial family were exiled so that their lines might disappear. Two birds died but hopes rose in 1983 when two of the remaining four birds paired. The female died, however, from a blocked fallopian tube shortly before she laid her eggs.

This year, the romance between $\mathrm{Kin}$ and Midori was followed closely but to no avail. As well as being in ripe old age, $\mathrm{Kin}$, having been reared in captivity, apparently did not take too well to Midori, who had led $a$ life in the wild until 1981.

The Sado Island Toki Centre is now to advance research on artificial insemination as fast as possible, but researchers doubt whether practical methods can be developed in time. Hopes for saving Nipponia Nippon from extinction now rest largely with the Chinese. In 1980, seven birds were found in China, raising the known numbers there to fourteen - the same as the number remaining in Japan. There have been occasional rumours of sightings in Korea and the southeastern Soviet Union, but none has been confirmed.

Alun Anderson 